\title{
Archaeological Testing for the Walker Ranch Park Bridge Project (41BX1271), San Antonio, Bexar County, Texas
}

Barbara A. Meissner

Follow this and additional works at: https://scholarworks.sfasu.edu/ita

Part of the American Material Culture Commons, Archaeological Anthropology Commons, Environmental Studies Commons, Other American Studies Commons, Other Arts and Humanities Commons, Other History of Art, Architecture, and Archaeology Commons, and the United States History Commons

Tell us how this article helped you.

This Article is brought to you for free and open access by the Center for Regional Heritage Research at SFA ScholarWorks. It has been accepted for inclusion in Index of Texas Archaeology: Open Access Gray Literature from the Lone Star State by an authorized editor of SFA ScholarWorks. For more information, please contact cdsscholarworks@sfasu.edu. 


\section{Archaeological Testing for the Walker Ranch Park Bridge Project (41BX1271), San Antonio, Bexar County, Texas}

\section{Creative Commons License}

\section{(c) (1) \&}

This work is licensed under a Creative Commons Attribution-NonCommercial 4.0 International License 


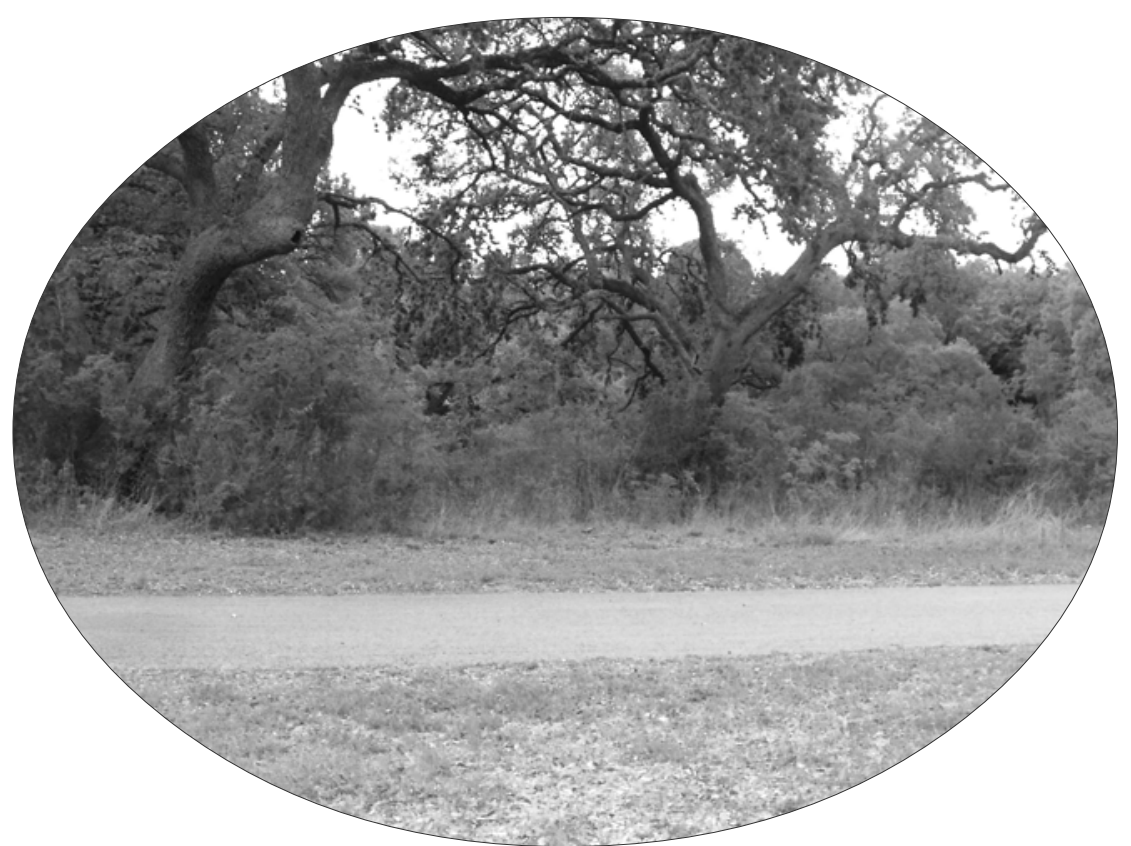

\title{
Archaeological Testing for the Walker Ranch Park Bridge Project (41BX1271), San Antonio, Bexar County, Texas
}

\author{
by \\ Barbara A. Meissner \\ with a contribution by \\ I. Waynne Cox
}

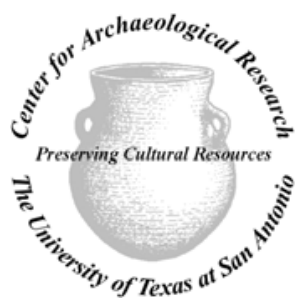

Archaeological Report, No. 365

Center for Archaeological Research

The University of Texas at San Antonio (C) 2006 


\title{
Archaeological Testing for the Walker Ranch Park Bridge Project (41BX1271), San Antonio, Bexar County, Texas
}

\author{
by \\ Barbara A. Meissner \\ with a contribution by \\ I. Waynne Cox
}

Steve A. Tomka

Principal Investigator

Texas Antiquities Permit No. 4116

Prepared for: City of San Antonio

Parks and Recreation Department

San Antonio, Texas

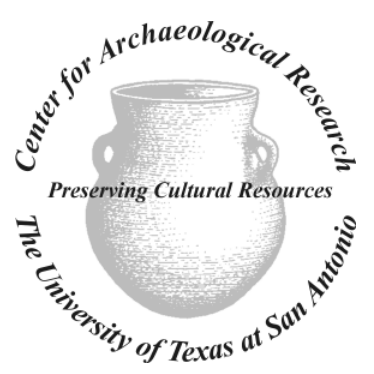

Center for Archaeological Research The University of Texas at San Antonio Archaeological Report, No. 365 
A list of publications offered by the Center for Archaeological Research is available. Call (210) 458-4378; write to the Center for Archaeological Research, The University of Texas at San Antonio, One UTSA Circle, San Antonio, Texas 78249-1644; e-mail to car@lonestar.utsa.edu; or visit CAR's web site at http://car.utsa.edu. 


\section{Abstract}

In April 2006 the Center for Archaeological Research (CAR) of the University of Texas at San Antonio was contracted by the Parks and Recreation Department of the City of San Antonio to perform subsurface investigations within the boundaries of site 41BX1251, in north-central San Antonio, Bexar County, Texas. The purpose of the testing was to learn if the concrete abutment of a planned pedestrian bridge over Salado Creek would impact significant archaeological deposits in this site, which is a part of the Walker Ranch National Historic District.

Five shovel tests and one backhoe trench were excavated. The shovel tests were placed within the footprint of the abutment and the backhoe trench was place approximately $10 \mathrm{~m}$ west of the shovel tests. Two artifacts were recovered from the shovel tests: a small piece of asbestos tile and a small piece of chert debitage. Three artifacts were observed in the backhoe trench: a piece of modern glass and two pieces of chert debitage. All artifacts were located in the upper $30 \mathrm{~cm}$ of sediments. No significant cultural deposits were encountered in the tests. It was recommended that the construction work continue as planned, and that no further archaeological work would be needed. 


\section{Table of Contents}

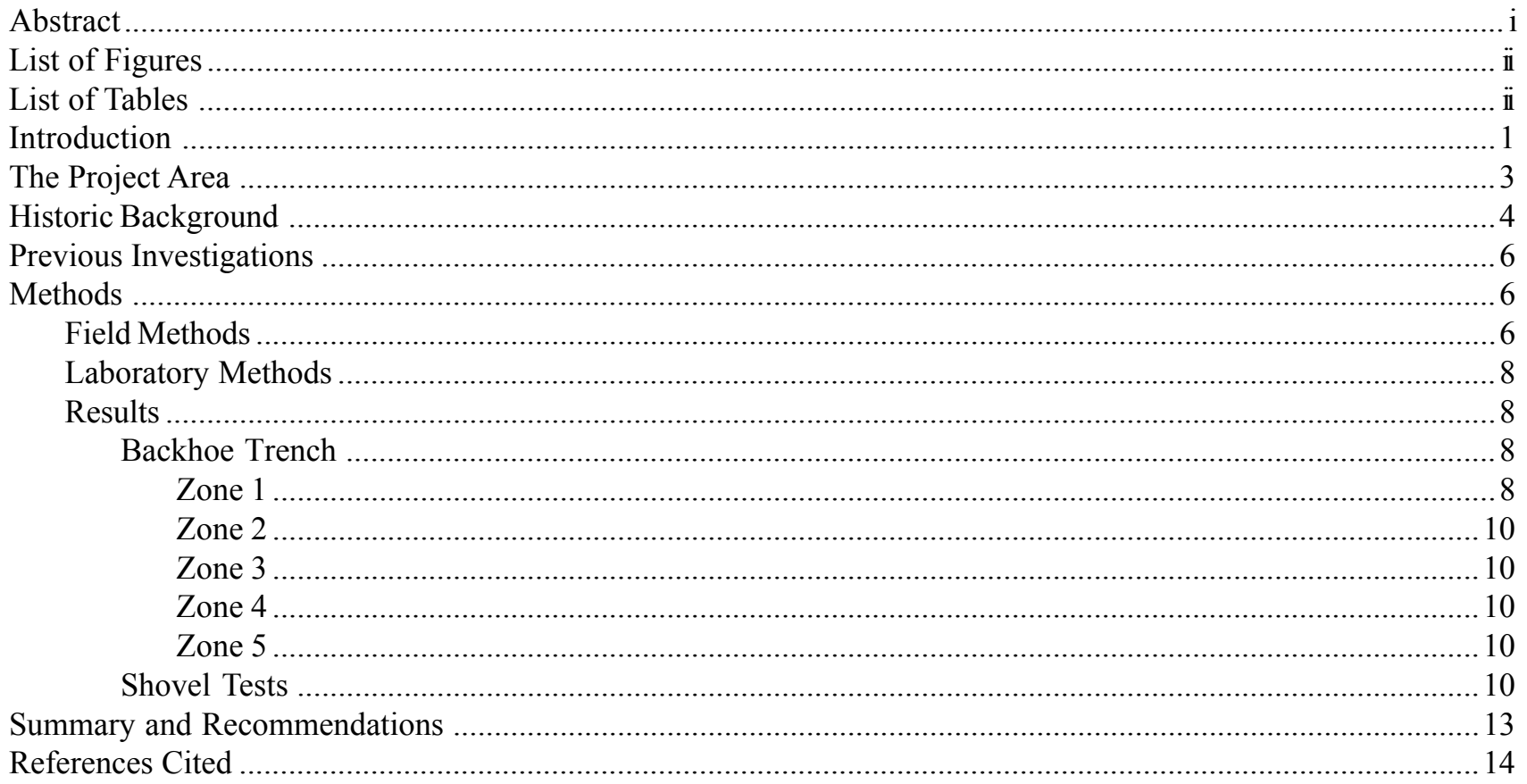

\section{Figures}

Figure 1. Location of Walker Ranch Park within the city of San Antonio. ........................................................ 1

Figure 2. Walker Ranch Park depicting existing park facilities and location of proposed bridge abutment..............2

Figure 3. Photograph of project area before excavations began, facing south. .................................................. 3

Figure 4. Detail of the project area showing the position of the backhoe trench and shovel tests. ......................... 7

Figure 5. View of the completed backhoe trench. Note the differences in sediment color in the back dirt. Also note the flagging tape marking a winged elm tree to ensure it would not be damaged. ................................... 8

Figure 6. Profile of the west wall of the backhoe trench. .................................................................................

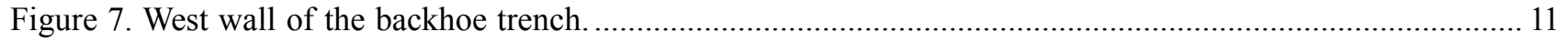

\section{Tables}

Table 1. Sediment Descriptions and Artifacts Recovered from Shovel Tests, by Level. 


\section{Introduction}

In April 2006 the Center for Archaeological Research (CAR) of the University of Texas at San Antonio was contracted by the Parks and Recreation Department of the City of San Antonio to perform subsurface investigations in the form of shovel testing and backhoe trenching, if possible, in the area to be directly impacted by the construction of a bridge within the confines of Walker Ranch Park and inside the boundaries of site 41BX1271, in north-central Bexar County, Texas (Figure 1). Walker Ranch Park is situated within the Walker Ranch Historic District (Hudson et al. 1974), designated in 1975, however site 41BX1271 was not documented until 1998 during a survey of the park by CAR(Tomka 1998).

The Parks and Recreation Department's current improvement plans for Walker Ranch Park include the construction of a footbridge over Salado Creek. The only major impact on the site during this project will be the construction of a concrete abutment for the bridge, which will be placed on the first terrace of Salado Creek approximately $10 \mathrm{~m}$ north of the northern edge of the creek bed, on the southern edge of 41BX1271 (Figures 2 and 3).

In order to ensure that no important historic or prehistoric cultural deposits are located within the area to be affected by this project, the Scope of Work (SOW), outlined by CAR and approved by the Texas Historical Commission (THC), required shovel testing of the Area of Potential Effect (APE). In addition, a backhoe trench was to be excavated to allow examination of the sediment profile if there was enough room between the existing sidewalk and the edge of the terrace.

In accordance with the SOW, five shovel tests and one short backhoe trench were excavated by staff archaeologists from CAR on May 1, 2006, working under Texas Antiquities Permit No. 4116. This report records the results of these

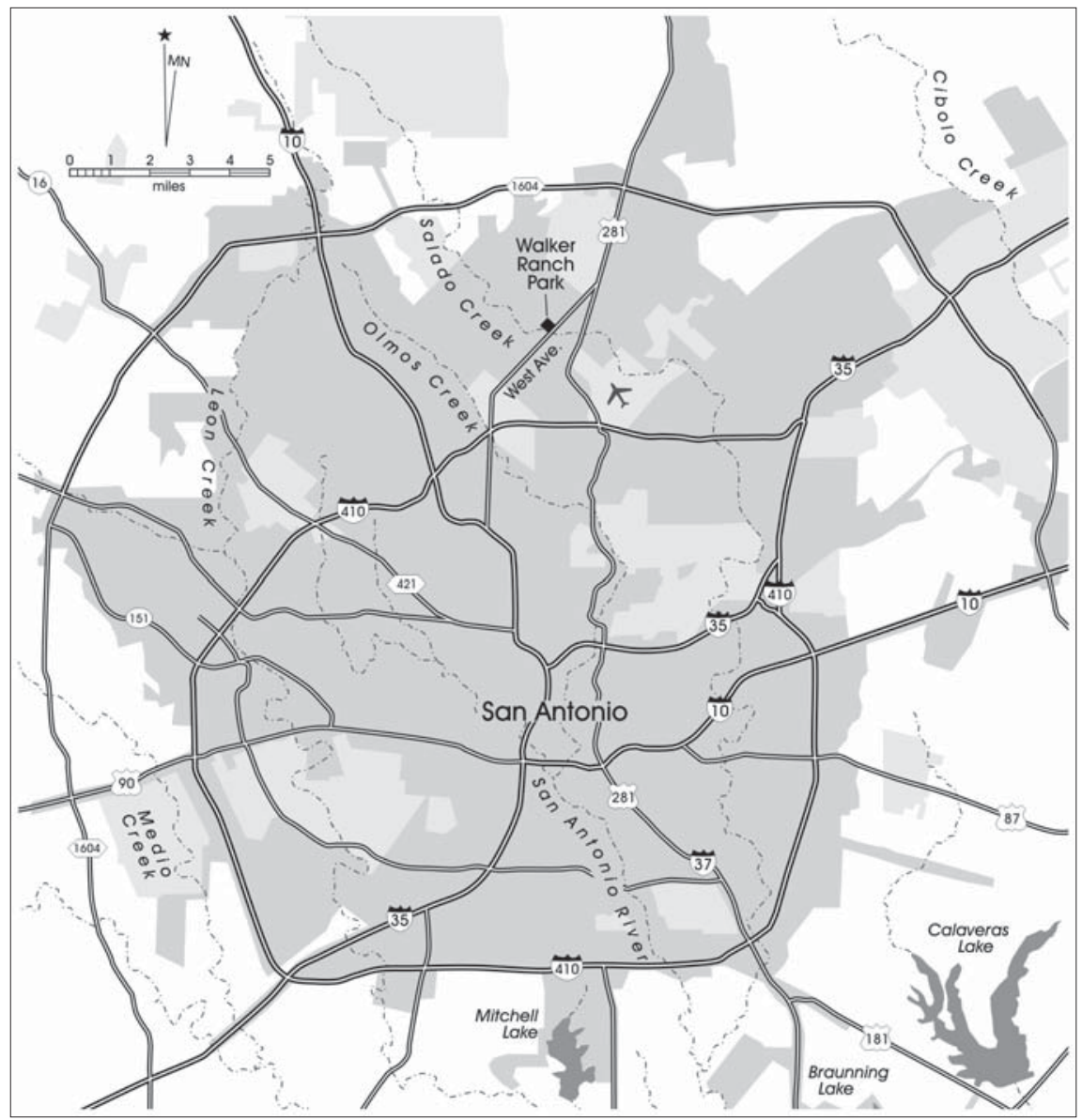

Figure 1. Location of Walker Ranch Park within the City of San Antonio. 


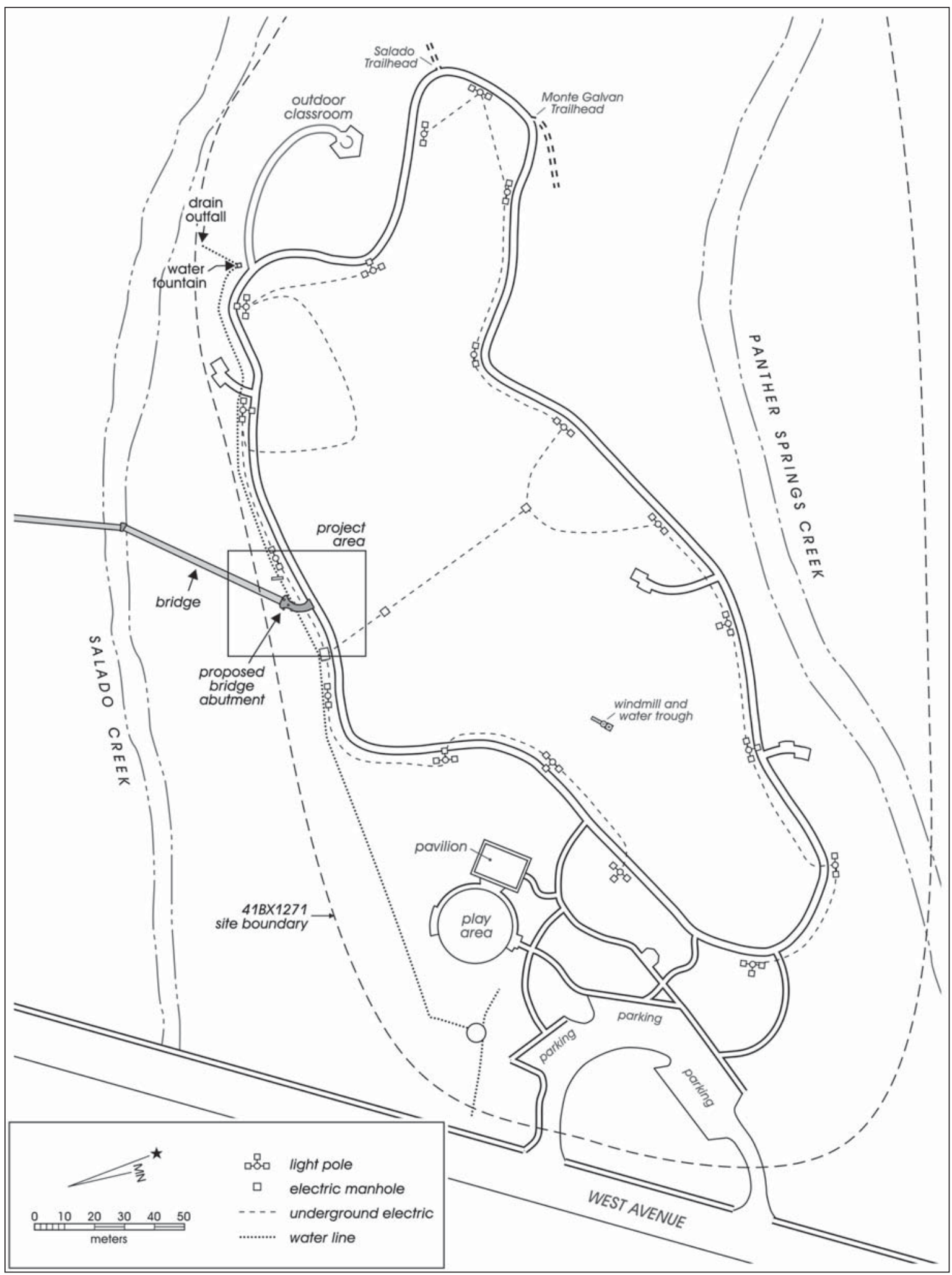

Figure 2. Walker Ranch Park depicting existing park facilities and location of proposed bridge abutment. 


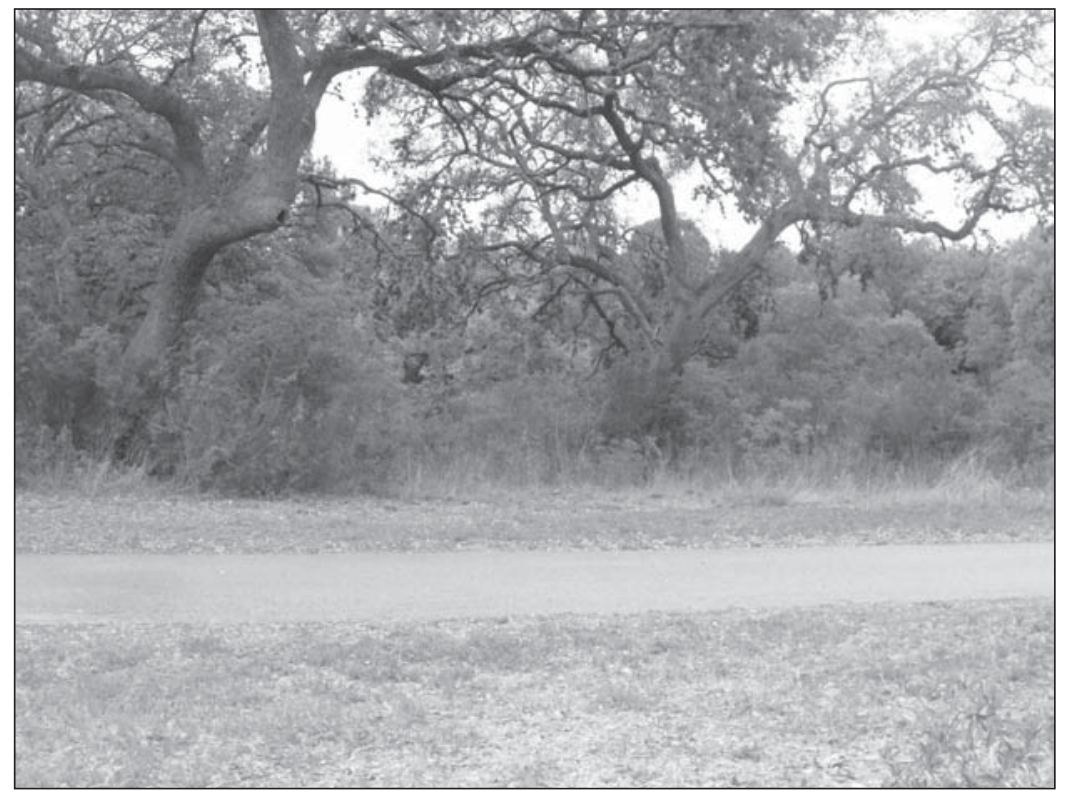

Figure 3. Photograph of project area before excavations began, facing south.

excavations. The Project Archaeologist was Barbara A. Meissner, assisted in the field by Lindy Martinez. Steve A. Tomka, the CAR Director, served as Principal Investigator. Steve Uncapher of the City of San Antonio Department of Parks and Recreation provided liaison with the City, located the APE, and provided the backhoe, along with operator Rosendo Valdéz. Mapping was completed by Bruce Moses, and Claudia Branton was the technical editor.

\section{The Project Area}

The climate of Bexar County is a subtropical, with warm winters and hot summers. The average winter temperature is $58^{\circ} \mathrm{F}\left(14^{\circ} \mathrm{C}\right)$ and the average summer temperature is $80^{\circ} \mathrm{F}\left(27^{\circ} \mathrm{C}\right)$ (Bomar 1995). Rain averages $787 \mathrm{~mm}$ (31 in) a year, but is extremely variable (Norwine 1995:139-140).

The immediate project area is located in the Upper Salado Creek watershed (Potter et al. 1995:7), west of West Avenue between the upper reaches of Salado Creek and Panther Springs Creek, about $1.6 \mathrm{~km}$ upstream of their confluence (Figure 2). This area is along the southern border of the Edwards Plateau, in the Balcones Canyonlands natural sub-region of Texas (LBJ School of Public Affairs 1978). The landscape consists of many steep-sided canyons cut into Cretaceous limestone deposits by high-gradient spring and rain-fed creeks that run generally south and east, joining the San Antonio and Medina Rivers and flowing to the Gulf of Mexico (Riskind and Diamond 1988:1).
The soils in the park are part of the Tarrant-Brackett association (Taylor et al. 1991) and consist of Lewisville Series silty clays. These soils are common on terraces above the flood plains of larger creeks. The solum (the upper portion of the soil profile, where soil processes are active) is 50-150 cm deep (Taylor et al. 1991:113), and therefore has a strong potential to contain buried cultural deposits.

Present-day vegetation in undeveloped areas along northern Bexar County consists of mixed evergreen and deciduous woodlands grading into deciduous woodlands and then into forest in the riparian setting of the deep canyons (Van Auken 1988). Dominant woody species along Salado Creek near the project area include Escarpment live oak (Quercus fusiformis); ashe juniper (Juniperus ashei), which is known locally as mountain cedar; cedar elm (Ulmus crassifolia), and netleaf hackberry (Celtis laevigata). Red buckeye (Aesculus pavia) and winged elm (Ulmus alata) saplings have been planted in the immediate area of the project.

Historic documentation, however, records a distinct change in the plant and animal communities of South Texas in response to Euro-American land and water use practices of the last 200 years. Overgrazing and the control of wildfires have resulted in an expansion of brushy species, especially various species of mesquite (Prosopis spp.), huisache (Acacia farnesiana), blackbrush (Acacia rigidula) and whitebrush (Aloysia gratissima) from the mottes to 
which they were once limited to dominate the landscape (Inglis 1964). Before these changes the vegetation along the southeastern border of the Edwards Plateau was predominately grasslands with woodland and forests limited to hillsides and deeply incised canyons (Weniger 1988).

From the point of view of the prehistoric hunter-gatherer groups who inhabited south Texas, Bexar County was a land rich in resources. Bexar County is located at the juncture of several major biotic and physiographic regions, providing a diverse and dynamic biological setting. Potter et al. (1995:23) note the presence of five biotic zones in the county, providing a wide diversity in biotic resources. Each of these zones provides a somewhat different set of plant and animal communities, allowing a flexible response to fluctuations in weather and resource availability (Nickels et al. 1997). Year-round resources included whitetail deer (Odocoileus virginianus), cottontail rabbits (Sylvilagus spp.), jackrabbit (Lepus californicus), wild turkey (Meleagris gallopavo), and numerous small mammals, as well as pricklypear (Opuntia spp.). From late summer into early winter, pecans (Carya illinoinensis), hickory nuts (Carya spp.), walnuts (Juglans spp.) and acorns (Quercus spp.) would have been abundant in most years (Tomka et al. 1997). Important non-biotic resources include large quantities of high-quality chert, the preferred stone for making stone tools, which erodes, sometimes in large nodules, from the limestone in the northern half of the county. Chert is also available as cobbles in creeks and rivers all over the county (Loomis et al. 1992).

The other major non-biotic resource in Bexar County is water. The Edwards Aquifer is one of the largest sources of fresh groundwater in the world (Eckhardt 2006). Water from the southern part of the Edwards Plateau flows south into the region of the Balcones Fault. In Bexar County this fault lies along the northern third of the county. The water follows numerous cracks and fissures in the faulted limestone and seeps into the underlying Edwards limestone (Eckhardt 2006). The water reappears in numerous springs across eight counties. Water was thus readily available in large quantities in the region. In recent decades the pumping of water from the Edwards Aquifer to provide for a large city (San Antonio), numerous smaller towns, and for irrigation has led to lowering of the level of the aquifer to the point that many springs are frequently dry, running only after large amounts of rain have fallen (Meissner 2000a:5).

Though most of the creeks of northern Bexar County are ephemeral today, some of the major creeks, such as Salado Creek, were permanent or nearly permanent sources of water before modern pumping began. The presence of so much water in the hot climate of Bexar County led to a prehistoric presence in the area dating to at least 11,500 BP (McKinney 1981; Story 1985), and was directly responsible for the choice of the San Antonio area for colonization by the Spanish, beginning in 1718 (Habig 1968:37; Meissner 2000a:10).

\section{Historic Background}

\section{By I. Waynne Cox}

As part of CAR's goal of providing a historical context to its projects, the following section is included in this report. This summary of information about the previous owners of Walker Ranch is based on a draft manuscript by the late Waynne Cox, founded on his many years of research, especially in the Bexar County Deed Records (BCDR). Unfortunately some of the references in the draft could not be identified, as they were notes to himself, not complete bibliographic references. In many cases we have been able to identify alternative references for the statements contained in his text. The original has been reorganized and considerably shortened, but the substance of this history is Waynne's work.

An extended archival search failed to reveal any Spanish titles or references concerning the property now known as Walker Ranch. The first transaction available currently is a record of the first-class head right granted to Sterling N. Dobie (Texas General Land Office [TGLO] 2006a), and an S. M. Dobie listed in 1846 as Patentee of a first-class head right originally granted to James B. Thompson (TGLO 2006b). It is possible, but cannot currently be confirmed, that this was the Sterling $M$. Dobie who was the son of a major Harris County rancher and the grandfather of the late historian J. Frank Dobie (Gregg 2006). If so, it is doubtful that Dobie ever occupied the ranch, for the transfer of the property to Joseph Alexander Crews occurred in Houston. This transfer occurred February 22, 1842 (BCDR D2:22).

Less than eight months later, on September 11, 1842, while serving as a Peace Officer for the District Court, Joseph Crews, along with several judges, lawyers and others at the court that day, was captured by General Adrián Woll, during the sack of San Antonio. This invasion by Mexico was part of a campaign of harassment fostered by President Santa Anna, as part of his refusal to acknowledge the independence of Texas from Mexico (Gunn 2006). Crews was one of the 52 men taken by the Mexicans back to Perote prison in Mexico. Though most of these men were later 
released, Crews was not among them. He died in Perote about February 1, 1844 (Winkler 1910). Since he died intestate, his estate passed to his principal heirs, his father Thomas, his wife, Fanny, and others (BCDR M-1:503-507).

On March 3, 1846, the property was sold at public auction by the sheriff for non-payment of taxes, and was purchased by a local merchant and land investor, Peter (née Pierre) Odet. Early the next year Crews' heirs, unaware of the action, transferred all their Texas property to an agent for resale. They apparently discovered the title difficulty much later, for in May of 1856, they brought suit against Odet, which ended in out-of-court settlement (Bexar County District Court Records [BCDCR] Document \#1722). In his statement to the court Odet testified he "has been in peaceable adverse posession of such land for more than five years, cultivating the same and paying taxes thereon..." and further that "...he has made valuable improvements thereon said land during this time, he had possession of the same and before the commission of this suit, defendant alleges that same improvements are of the value of \$2000" (BCDCR: Document \#1722). An archaeological project in 1979 recorded some of these improvements, including the remains of two stone structures, a house and an outbuilding (Fox 1979:8).

In 1858 the land was sold once more. Apparently to insure a clear title, Edward Higgins paid both Odet and the Crews heirs a combined total of $\$ 2050$ for the property on May 18 , 1858 (BCDR P-2:630-652). Higgins, the most interesting of the former owners of Walker Ranch, was born in Norfolk, Virginia in 1821 (Warner 1959:134). While living with his uncle in Iberville Parish, Louisiana, he received an appointment as a midshipman in the U.S. Navy, at the age of 14. He resigned as a Lieutenant in 1854 to enter the Steamship Mail service between New York and New Orleans, and then apparently moved to San Antonio, purchasing the land now known as Walker Ranch in 1858 (BCDR P-2: 630-652). Very little is known about Higgins' time in Bexar County, except that, in December 1859, eighteen months after purchasing the ranch land, he mortgaged the property to Harriet Eliza Thompson for \$2000 (BCDR R-1:652).

On February 16, 1861, only two weeks after the Ordinance of Session was voted on by the Secession Convention and a week before the popular vote to ratify the Ordinance, Major General David E. Twiggs, Commander of the Department of Texas, headquartered at the Alamo, surrendered all federal forces and property to the State of Texas after a token refusal (Bowden 1986:2-3). On March 1, General Twiggs was dismissed by President Buchanan for "treachery against the flag of his country" (Crimmins 1938:172).

Twiggs left Texas for Louisiana and in May of 1861, was commissioned a Major General in the Confederate Army. He was briefly in command of the District of Louisiana, until ill health forced his retirement (Warner 1959:312). At approximately the same time, Higgins also left for Louisiana, where he joined the Confederate Army as a Captain in the $1^{\text {st }}$ Louisiana Artillery and was selected by General Twiggs as his aide-de-camp (Warner 1959:134).

Promoted to Lieutenant Colonel, Higgins was placed in command of Forts Jackson and St. Phillips, defending the approach to New Orleans. In April of 1862 the Forts were attacked by the fleet of Admiral David Porter. After a devastating bombardment, Higgins was forced to surrender (Official Records (OR) Series 1, Vol. 6:544-545). Paroled and promoted to Colonel, Higgins was assigned to the river defenses for Vicksburg, Mississippi, was captured again on July 4, 1962, and re-paroled (OR Series 1, Vol. 24:340). He was promoted to Brigadier General in October 1863, and at the express request of Major General Dabney Maury, commander of the district, was placed in charge of the harbor and port defenses of Mobile, Alabama (Warner 1959:134).

Here, however, something seems to have gone wrong with the military career of Edward Higgins. The Official Records contain a note from General Maury stating "General Higgins left his station here by his own act when he believed an immediate attack was to be made upon the works under his command. He absented himself from this district without my authority, or that of any one else, so far as I know, and has been absent more than a month" (OR Series 1, Vol. 39:847). Although apparently not court-martialed, Higgins did not receive another command and was "waiting for orders" in Macon, Georgia in February 1865 (Warner 1959:134). After the war, Higgins returned to Virginia until 1872, when he moved to San Francisco. He died there three years later (Warner 1959:134).

There is no evidence that he ever returned to Texas. He also did not pay his debt to Mrs. Thompson. In November of 1869, she sued Higgins for non-payment of the mortgage. After several delays the court awarded the property to Harriet Eliza Thompson in January of 1873; however, she had died in August of 1872. Her heir, Jennie W. de Ganahl, petitioned the court on November 26 and was awarded the property as sole heir (BCDCR H:218). On June 18, 1874, Jennie and her husband, Charles, received clear title. They 
resurveyed the property, divided it into fifty equal lots, and sold six lots, probably to pay the surveyor (BCDR 4:13). Charles de Ganahl had signed the Ordinance of Secession as the delegate from Kerr County and later served as a Surgeon in the Confederate Army (Civil War Soldiers and Sailors System 2006). In February of 1884, Mrs. de Ganahl sold a new right-of-way for Blanco Road to the city (BCDR 33:396). On July 19, 1897, Charles F. de Ganahl sold the property to his sister, Charissa Ganahl Walker (she did not retain the original spelling of her surname) (BCDR 166:26). The family still owned a large part of the original ranch when the Walker Ranch Historic District was established in 1975 (National Register of Historic Places 2006).

\section{Previous Investigations}

Twenty-six archaeological sites have been identified within the Walker Ranch National Historic District, and another $30-40$ sites in the near vicinity (Texas Historical Commission 2006). This rich archaeological heritage was first recognized beginning in the 1970s (Hudson et al. 1974). Walker Ranch National Historic District was established in 1975. CAR's investigation of the historic site 41BX180 (Fox 1979) was followed by several other CAR investigations in the area, including many prehistoric sites (Potter 1980; Black and McGraw 1985). Archaeological investigations conducted as part of the Wurzbach Parkway Project within the Walker Ranch National Historical District also identified and tested several sites (see Potter et al. 1995; Black et al. 1998).

The first archaeological work conducted in the Walker Ranch Park was in 1997 (Tomka 1998) in preparation for construction of the park trail, parking lot, playground and pavilion areas. The survey conducted by CAR identified a thin scatter of non-diagnostic prehistoric materials over much of the park and two concentrations of historical materials (Tomka 1998). Based on this work most of the park was designated as archaeological site 41BX1271. As a result of this designation the Parks and Recreation department contracted with CAR in 2000 to monitor excavation of the footprint for an outdoor classroom facility in the western end of the park, and modification of the path leading to this facility to make it compliant with the Americans with Disabilities Act (Meissner 2000b). The latter part of the project involved removing an area of bedrock that extended to the ground surface. Meissner (2000b:5) identified a thin scatter of lithic debitage over the footprint of the proposed facility, a butted chert knife nearby, and a small dump of twentieth century artifacts.
In January of 2003 a crew from CAR conducted an archaeological survey and geoarchaeological investigations at the park (Weston 2003). The work was done in advance of planned installation of security lights around the existing trail and placement of a drinking fountain on southern side of the park, near Salado Creek. A 100\% pedestrian survey was conducted and 41 shovel tests were completed. In addition, two shovel tests were expanded to $50-\mathrm{x}-50-\mathrm{cm}$ units to expose profiles for a geoarchaeological assessment (Greaves 2003). The results confirmed that there is a low-density lithic scatter over much of the park, with most positive shovel tests in the northern and western part of the park (Weston 2003:7). Of the shovel tests from both the 1997 and 2003 projects near the current project (STs 22, 50, and 51), only ST 22, located approximately $30 \mathrm{~m}$ east of the current project, was positive, producing four flakes of chert debitage (Tomka 1998:2, 13; Weston 2003:7).

During the 2003 project Greaves (2003:13) noted that there was evidence in both profiles that the upper part of the A horizon had been removed, presumably by mechanical scraping, at some time in the past. Beneath this disturbance, however, there appeared to be undisturbed sediments of varying depths above weathered limestone bedrock. Greaves also noted that the oldest terraces in the developed part of the park were in the north-central area, near Panther Springs Creek. Most importantly, he noted that except for the removal of part of the A horizon in at least part of the park, there is no evidence that cultural deposits in areas away from recent construction have been disturbed, and thus the potential for features with archaeological integrity within the park is good (Greaves 2003:14).

\section{Methods}

\section{Field Methods}

Steve Uncapher, of the city Parks and Recreation Department, met with CAR staff at the site the morning of May 1, 2006. He marked the location of the abutment, and requested that the backhoe trench not be dug within the APE, due to concerns about insufficient soil compaction in a backfilled trench. Instead, he approved a location approximately $10 \mathrm{~m}$ west of the APE where there was room for a short backhoe trench between small trees he did not want disturbed, and a point approximately $1.5 \mathrm{~m}$ south of the existing sidewalk (Figure 4). The area immediately south of the sidewalk could not be disturbed due to existence of buried electrical and water utility lines (Figure 2). 
The purpose of the mechanical excavation was to search for cultural deposits buried below the reach of the standard shovel tests to be excavated within the project area. The backhoe trench was dug with a 61-cm (24-in) bucket. The trench was $370 \mathrm{~cm}$ long. Each scoop was approximately $10 \mathrm{~cm}$ deep. The archaeologist watched carefully, stopping the digging whenever a closer look at sediments was needed, and examining the backdirt. The trench was dug to approximately $140 \mathrm{~cm}$ deep. In compliance with the SOW, artifacts encountered during digging of the trench were noted but not collected. After the digging was completed the west profile of the trench was recorded by scale drawing and digital photographs. The exact location of the trench was determined with a Trimble Geo Explorer II GPS unit. The backhoe trench was then backfilled. As requested by Steve Uncapher, care was taken to avoid damage to young trees growing near the trench during this work (Figure 5).

Before shovel tests were completed a surface survey of the abutment footprint and the immediate area was done. No artifacts were noted. One large $(\mathrm{ca} .20 \mathrm{~cm})$ chert cobble that appeared to have been tested was noted west of the backhoe trench, but since this was well outside the APE it was not recorded.

A total of five shovel tests were dug to test the footprint of the bridge abutment. ST 1 was placed in the center of the footprint as marked by Steve Uncapher and STs 2-5 were placed approximately $2 \mathrm{~m}$ north, south, east and west of ST 1 (Figure 4). Shovel tests were approximately $30 \mathrm{~cm}$ in diameter and were dug in arbitrary $10-\mathrm{cm}$ levels. All sediments from the tests were screened through $.64-\mathrm{cm}(1 / 4-$ in) hardware cloth. Each test was recorded on a shovel test form, and each level was recorded separately on that form. Information recorded included a description of the texture and color of the sediments, notes on inclusions, and a count of artifact types encountered. All field forms were completed with pencil. Artifacts were bagged by shovel test and level. Photographs of each completed shovel test were taken and the exact location determined with a Trimble Geo Explorer II GPS unit. A small soil sample of each sediment type encountered in ST 1 was taken.



Figure 4. Detail of the project area showing the position of the backhoe trench and shovel tests. 


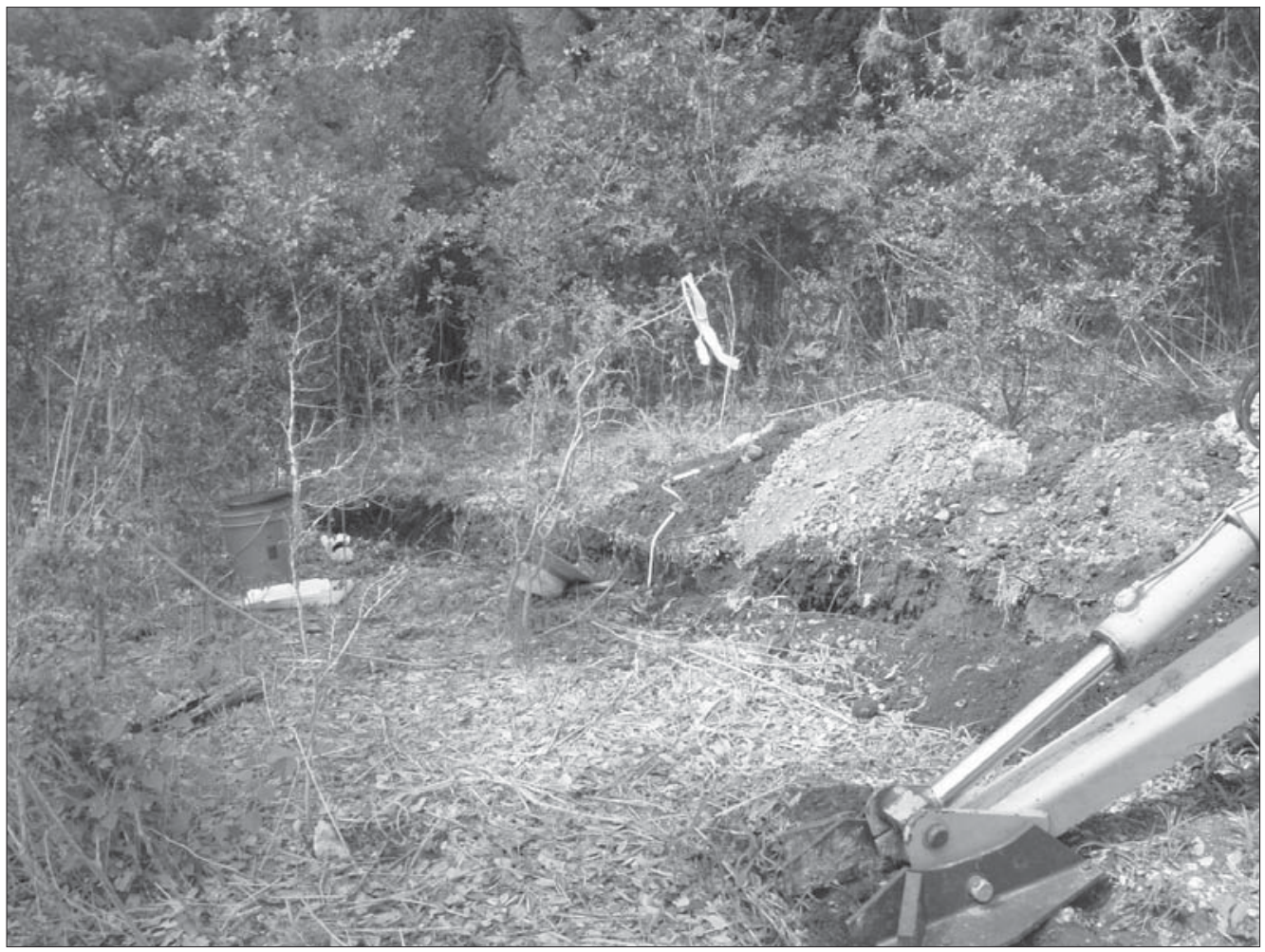

Figure 5. View of the completed backhoe trench. Note the differences in sediment color in the back dirt. Also note the flagging tape marking a winged elm tree to ensure it would not be damaged.

\section{Laboratory Methods}

All cultural materials and records obtained and/or generated during the project will be prepared in accordance with federal regulation 36 CFR Part 79, and THC requirements for State Held-in-Trust collections and curated at the CAR facility. Artifacts processed in the CAR laboratory were washed in tap water, air-dried and stored in 4-mm zip-locking, archival-quality bags. Labels were placed in all artifact bags. Each label contains provenience information and a lot number laser printed on acid-free paper. A catalog of the artifacts was generated, printed on acid-free paper, and will be included in the site records, along with a CD containing digital versions of the report and all supporting documentation, including photographs. Digital photographs will be printed on acid-free paper and labeled with archivally appropriate materials and placed in archival-quality sleeves.

\section{Results}

\section{Backhoe Trench}

A mentioned above, the backhoe trench dug west of the abutment footprint was $370 \mathrm{~cm}$ long and approximately $140 \mathrm{~cm}$ deep. Figure 6 shows the west wall profile of the trench, and Figure 7 is a photograph of that wall. A geomorphologic analysis for this profile is not presented, as the primary purpose of the project was to ensure that no significant cultural deposits would be impacted by the construction of the bridge abutment. Five zones were noted in the profile, as follows:

\section{Zone 1}

Zone 1 in the profile is a roughly 20 to $25-\mathrm{cm}$ thick layer of dark brown, silty clay loam that is loose and friable. There is 


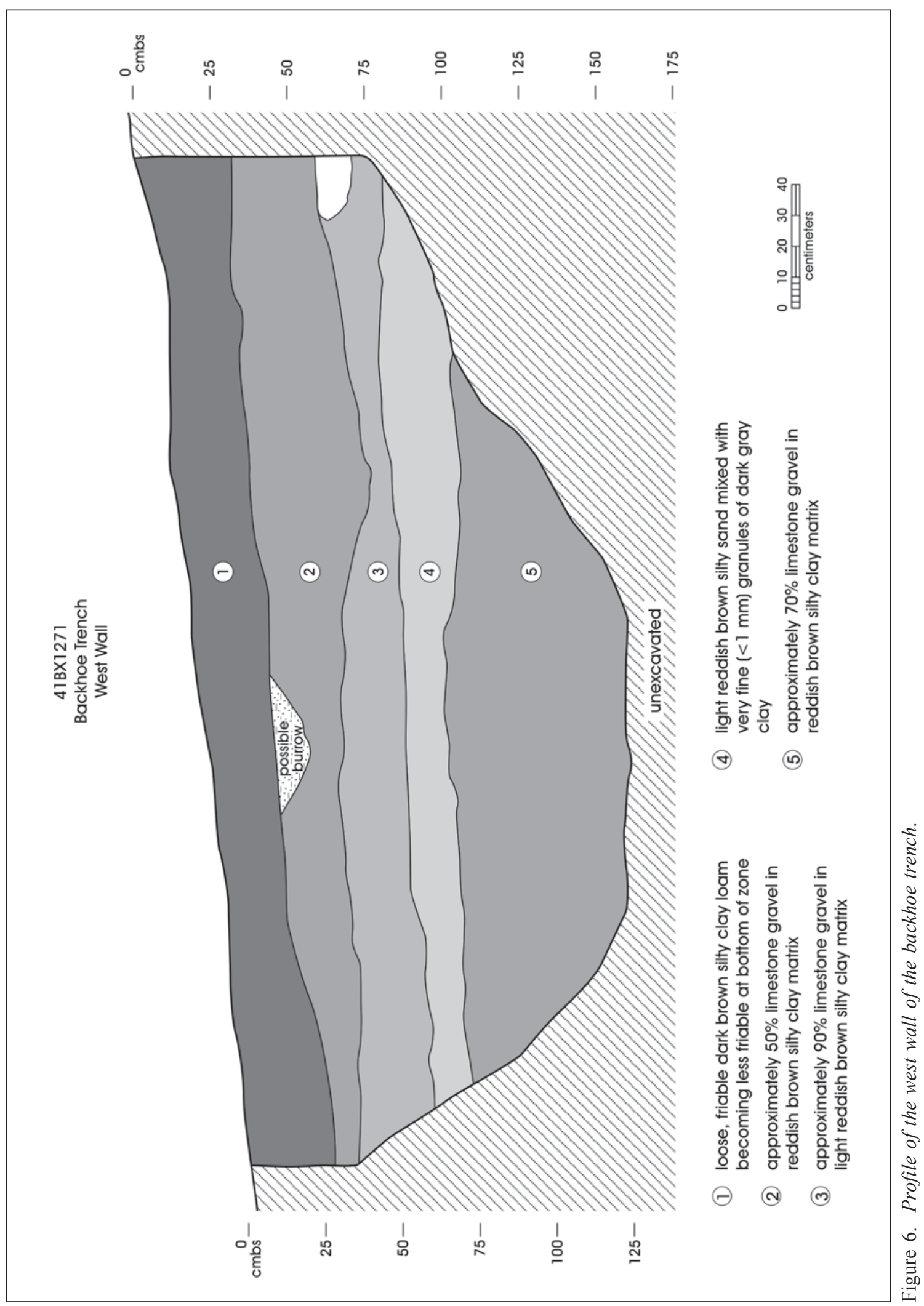


about $5 \%$ increasing to about $15 \%$ by volume of small ( $<2 \mathrm{~cm}$ or smaller), limestone rocks, most of which are coated with a thin layer of iron oxide. Occasional larger $(5-10-\mathrm{cm})$ limestone cobbles are present. This layer becomes gradually denser and less friable. With the exception of the possible burrow noted in Figure 6, the transition to Zone 2 is fairly abrupt with only about $1-2 \mathrm{~cm}$ of transition. Two chert flakes, each about $5 \mathrm{~cm}$ long, were encountered in Zone 1 but in accordance with the SOW, were not collected. In addition a sherd of bright green bottle glass that is of post- 1900 origin (U. S. Bureau of Land Management 2006) was observed but not collected. Due to the presence of both modern and prehistoric artifacts within the zone it was assumed that the materials were in disturbed context. This may not mean disturbance by humans. The clay soils can develop deep cracks when dry, into which items on the surface can fall. In addition, the possible animal burrow noted in the profile could have contributed to the disturbance.

\section{Zone 2}

Zone 2 is approximately $50 \%$ limestone gravels in a dense matrix of reddish-brown, silty clay. The gravels are somewhat angular, and flat, and minimally water-rounded. They range in size from $<1 \mathrm{~cm}$ to about $8 \mathrm{~cm}$ in length. Most are about $1-2 \mathrm{~cm}$ thick. Zone 2 is only about $5 \mathrm{~cm}$ thick at the southern end of the profile and is as much as $20 \mathrm{~cm}$ thick at the northern end (see Figure 6). The gravels appear white in the photograph (Figure 7) but this is because they have been scraped by the backhoe. All the gravel has thin coating of reddish iron oxide. The transition to Zone 3 is fairly abrupt, with the increase in percentage of rock very clearly marked. This zone seems to be the result of moderate-energy stream flooding.

\section{Zone 3}

Zone 3 is an almost solid layer (ca. 90\%) of gravel similar to that in Zone 2 but averaging somewhat larger in size. The matrix is densely packed, sandy clay of a light red-brown color. In general this layer is about $20 \mathrm{~cm}$ thick except in one place in the northern half of the profile where Zone 2 dips into it (Figure 6). This zone is the result of high-energy flooding. The transition to Zone 4 is abrupt.

\section{Zone 4}

Zone 4 is a layer of reddish, light brown sand mixed with very fine $(<1 \mathrm{~mm})$ granules of dark gray clay. The amount of gray clay varies in streaks across the profile. There is only about $5 \%$ or less limestone rock (most $<2 \mathrm{~cm}$ ) in this layer. The layer increases in thickness from south to north from about $10 \mathrm{~cm}$ to about $25 \mathrm{~cm}$. This zone represents low-energy, overbank deposits. The transition to Zone 5 is abrupt.

\section{Zone 5}

Zone 5 resembles Zone 2, but with a higher percentage of gravel (ca. 70\%). As was the case with the other gravel in Zones 2 and 3 most of the gravel is not markedly water-rounded. Gravel size range is larger in Zone 5, with some rocks reaching $10-15 \mathrm{~cm}$ in length. Although not markedly rounded, the gravels are high-energy flood deposits that had been transported only a relatively short distance. Zone 5 extended ca. $60 \mathrm{~cm}$, to the bottom of the trench.

Both Zones 2 and 4 increase markedly in depth to the north, accounting for the increase in ground level from south to north along the length of the trench. The thickness of Zone 5 was not determined. The only sign of cultural deposits in the backhoe trench was in the uppermost zone. Though the gravels below Zone 1 were carefully observed, no artifacts were noted, either in the walls of the trench or in the backdirt that was carefully examined.

\section{Shovel Tests}

Five shovel tests were dug during this project. The first test was placed at the center of the bridge abutment footprint, as marked by Steve Uncapher of the city Parks and Recreation Department. The other four tests were placed roughly $2 \mathrm{~m}$ from ST 1 (Figure 4). Table 1 shows the results of the shovel tests. Soil samples were only taken from ST 1.

As can be seen in Table 1, there are four layers of sediments encountered in the shovel tests. In all the shovel tests except ST 5, Layer 1 constitutes the upper $5-10 \mathrm{~cm}$ of sediments. Layer 1 is a loose, friable, silty clay loam, very dark brown (Munsell color number 7.5YR2.5/3). This sediment becomes increasingly dense and less friable without changing color for roughly another $5 \mathrm{~cm}$. Close examination of this layer in the laboratory shows that there are numerous tiny caliche nodules surface-stained with red iron oxides (7.5YR6/8), and a few calcium carbonate filaments.

Layer 1 grades fairly quickly into Layer 2, a dark yellowish brown (10YR3/3), silty clay with an increase in both number 
and size of the red-stained caliche nodules (some as large as $1 \mathrm{~mm}$ ), giving the field impression that the sediment is somewhat redder than the previous level. In addition there is an increase in the number of very small (ca. $0.5-1.5 \mathrm{~cm}$ ) limestone pebbles to about 10 to $15 \%$. This layer was not differentiated from Layer 1 in the backhoe trench. It is not known whether this is because Layer 2 did not appear in the backhoe trench, or was not as noticeable at the location of the backhoe trench.

The third layer is the equivalent of Zone 2 in the backhoe trench. This is an extremely hard-packed, silty clay. The matrix is dark brown $(7.5 \mathrm{YR} 3 / 3)$, but there were so many red-stained caliche nodules, calcium carbonate filaments, and tiny uncoated white limestone rocks that the field impression was that the sediment was much lighter and redder than it actually is. Approximately $50 \%$ of this layer is limestone gravel 1-8 cm in width. As described for Zone 2 in the backhoe trench, this gravel shows minimal if any water-rounding. The gravels are relatively flat and angular in appearance. In ST 1 an attempt was made to dig into this layer, but as the backhoe trench showed the layer below this was even denser gravel, ST 1 was terminated at $43 \mathrm{~cm}$ and all subsequent STs were terminated when it was clear that Layer 3 had been reached.

In ST 5 there is a 5-7-cm layer of much looser, sandier clay above the silty clay of Layer 1; we have designated this

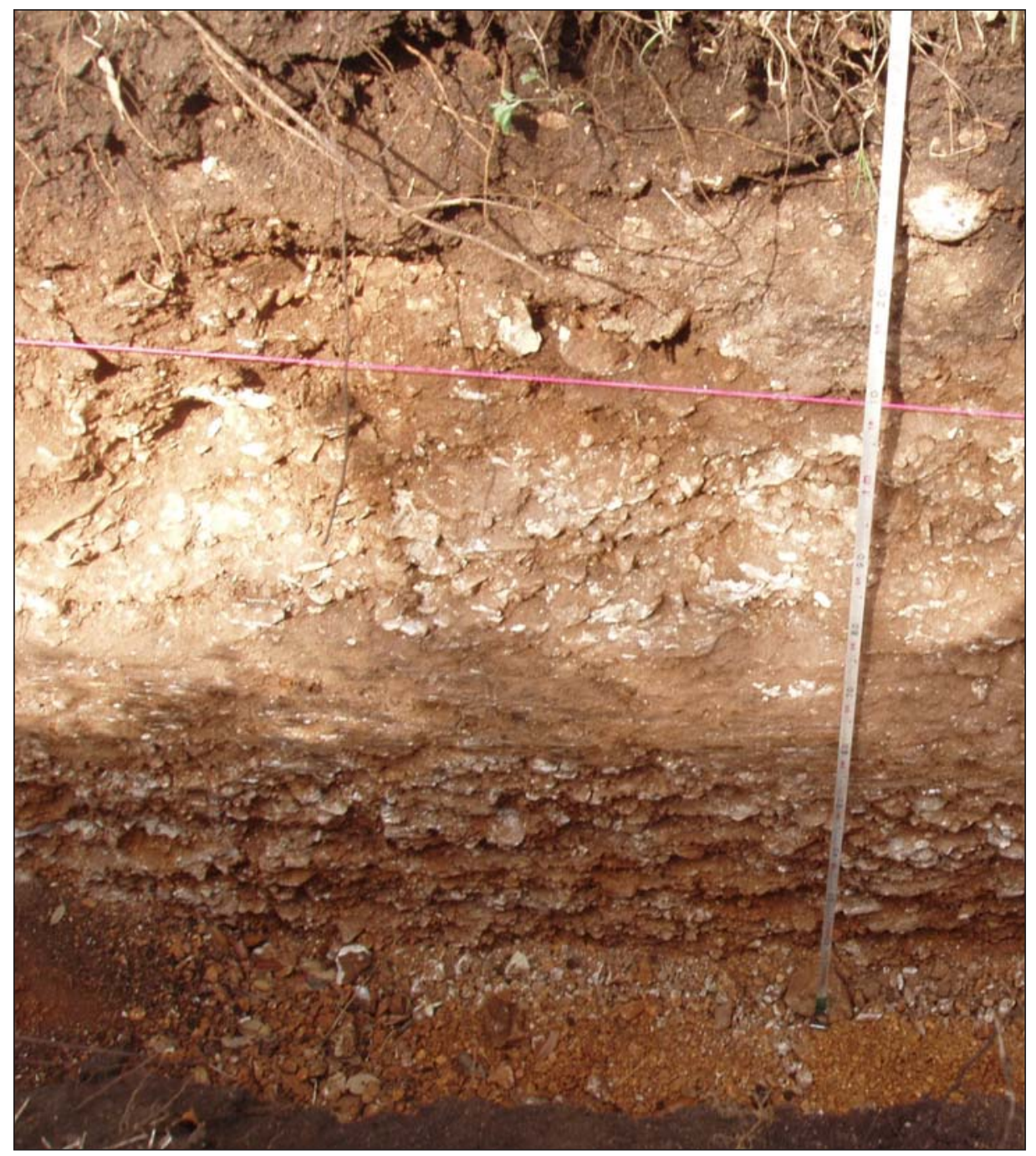

Figure 7. West wall of the backhoe trench. 
Table 1. Sediment Descriptions and Artifacts Recovered from Shovel Tests, by Level.

\begin{tabular}{|c|c|c|c|c|}
\hline Unit & Level & $\begin{array}{l}\text { Depth } \\
\text { (cmbs) }\end{array}$ & Sediment Description & $\begin{array}{l}\text { Artifacts } \\
\text { Recovered }\end{array}$ \\
\hline \multirow{5}{*}{ ST 1} & 1 & $0-10$ & $\begin{array}{l}\text { Dark brown friable silty clay loam with }<5 \% \text { gravels, becoming slightly more } \\
\text { dense at bottom of level. }\end{array}$ & ---- \\
\hline & 2 & $10-20$ & $\begin{array}{l}\text { As above, but becoming more dense and much less friable. Small gravels } \\
(<\text { pea-sized) increasing to ca. } 5 \% \text {. }\end{array}$ & ---- \\
\hline & 3 & $20-30$ & $\begin{array}{l}\text { Dense dark brown silty clay with density increasing sharply at ca. } 28 \mathrm{~cm} \text {. } \\
\text { Color changing to redder brown and increase in gravel to ca. } 10 \% \text { pea-sized } \\
\text { and a few larger limestone rocks (ca. } 5 \mathrm{~cm} \text { ). Small (ca. } 1 \mathrm{~mm} \text { or less) caliche } \\
\text { nodules, increasing with depth. }\end{array}$ & ---- \\
\hline & 4 & $30-40$ & $\begin{array}{l}\text { Beginng ca. } 36 \mathrm{~cm} \text { extremely hard, reddish-brown sandy clay with ca. } 50 \\
\text { gravels and numerous small caliche nodules. Similar to Zone } 2 \text { in backhoe }\end{array}$ & ---- \\
\hline & 5 & $40-43$ & $\begin{array}{l}\text { Increasing gravel size and content and continuing very dense, hard matrix. } \\
\text { Terminated at } 43 \mathrm{cmbs} \text {. }\end{array}$ & ---- \\
\hline \multirow{4}{*}{ ST 2} & 1 & $0-10$ & $\begin{array}{l}\text { Dark brown friable silty clay loam with }<5 \% \text { gravels, becoming noticabley } \\
\text { more dense and less friable at bottom of level. }\end{array}$ & ---- \\
\hline & 2 & $10-20$ & $\begin{array}{l}\text { Becoming even more dense, with increase in pea-sized gravel to ca. } 10 \\
\text { percent. A few small (ca. } 1 \mathrm{~mm} \text { or less) caliche nodules present. }\end{array}$ & ---- \\
\hline & 3 & $20-30$ & $\begin{array}{l}\text { Increasing density of silty clay continuing. Soil color becoming slightly lighter } \\
\text { and redder, possibly due to increased gravels }(15 \%) \text { and small caliche nodules. }\end{array}$ & ---- \\
\hline & 4 & $30-38$ & $\begin{array}{l}\text { As above to } 35 \mathrm{cmbs} \text {, where there is a sudden increase gravel content to ca. } \\
50 \% \text { and increase in gravel size to ca. } 5 \mathrm{~cm} \text {. Matrix changed to lighter reddish } \\
\text { sandy clay. Terminated at } 38 \mathrm{cmbs} \text {. }\end{array}$ & ---- \\
\hline \multirow{3}{*}{ ST 3} & 1 & $0-10$ & $\begin{array}{l}\text { Dark brown friable silty clay loam with }<5 \% \text { gravels, becoming noticably } \\
\text { more dense and less friable at bottom of level. }\end{array}$ & ---- \\
\hline & 2 & $10-20$ & $\begin{array}{l}\text { As above, but becoming more dense and much less friable. Small gravels } \\
(<\text { pea-sized) increasing to ca. } 5 \% \text {. At ca. } 18 \text { gravel increases to ca. } 15 \% \text { and } \\
\text { sediments become much harder, lighter and redder in color. Numerous small } \\
\text { caliche nodules }(<1 \mathrm{~mm}) \text {. }\end{array}$ & \\
\hline & 3 & $20-28$ & $\begin{array}{l}\text { As above to } 25 \mathrm{cmbs} \text {, where there is a sudden increase gravel content to ca. } \\
50 \% \text { and increase in gravel size to ca. } 5 \mathrm{~cm} \text {. Matrix changed to lighter reddish } \\
\text { sandy clay. Terminated at } 28 \mathrm{cmbs} \text {. }\end{array}$ & ---- \\
\hline \multirow{4}{*}{ ST 4} & 1 & $0-10$ & $\begin{array}{l}\text { Dark brown friable silty clay loam with }<5 \% \text { gravels, becoming noticabley } \\
\text { more dense and less friable at bottom of level. }\end{array}$ & ---- \\
\hline & 2 & $10-20$ & $\begin{array}{l}\text { Becoming even more dense, with increase in pea-sized gravel to ca. } 10 \\
\text { percent. A few small (ca. } 1 \mathrm{~mm} \text { or less) caliche nodules present. }\end{array}$ & $\begin{array}{c}1 \text { pc. asbestos } \\
\text { tile }\end{array}$ \\
\hline & 3 & $20-30$ & $\begin{array}{l}\text { At ca. } 26 \text { gravel increases to ca. } 15 \% \text { and sediments become much harder, } \\
\text { lighter and redder in color. Numerous small caliche nodules }(<1 \mathrm{~mm}) \text {. }\end{array}$ & ---- \\
\hline & 4 & $30-40$ & $\begin{array}{l}\text { As above to } 38 \mathrm{cmbs} \text {, where there is a sudden increase gravel content to ca. } \\
50 \% \text { and increase in gravel size to ca. } 5 \mathrm{~cm} \text {. Matrix changed to lighter reddish } \\
\text { sandy clay. Terminated at } 40 \mathrm{cmbs} \text {. }\end{array}$ & ---- \\
\hline
\end{tabular}


Table 1. Sediment Descriptions and Artifacts Recovered from Shovel Tests, by Level, contd...

\begin{tabular}{|c|c|c|c|c|}
\hline Unit & Level & $\begin{array}{l}\text { Depth } \\
\text { (cmbs) }\end{array}$ & Sediment Description & $\begin{array}{c}\text { Artifacts } \\
\text { Recovered }\end{array}$ \\
\hline \multirow{3}{*}{ ST 5} & 1 & $0-10$ & $\begin{array}{l}\text { Dark brown friable sandy clay loam with } 15 \% \text { pea-sized gravels, much sandier } \\
\text { and with more gravel than Level } 1 \text { of other STs, becoming dark brown friable } \\
\text { silty clay loam with ca. } 5 \% \text { pea-sized gravels, similar to Level } 1 \text { of other STs } \\
\text { by about } 5 \mathrm{cmbs} \text {. }\end{array}$ & $\begin{array}{l}1 \text { pc. chert } \\
\text { debitage }\end{array}$ \\
\hline & 2 & $10-20$ & $\begin{array}{l}\text { Dark brown friable silty clay loam with ca. } 5 \% \text { pea-sized gravels, similar to } \\
\text { Level } 1 \text { of other STs, becoming rapidly more dense and less friable at bottom } \\
\text { of level. }\end{array}$ & ---- \\
\hline & 3 & $20-26$ & $\begin{array}{l}\text { As above, grading quickly to hard-packed gravel, at least } 60 \% \text { and increase in } \\
\text { gravel size to ca. } 5 \mathrm{~cm} \text {. Matrix changed to lighter reddish sandy clay. Many } \\
\text { small caliche nodules. Terminated at } 26 \mathrm{cmbs} \text {. }\end{array}$ & ---- \\
\hline
\end{tabular}

Layer 4. This layer contains about $15 \%$ of pea-sized limestone gravel. The transition to the very dark brown, silty clay loam of Layer 1 is abrupt. It appears that Layer 1 is somewhat truncated in ST 5, with its upper surface replaced by Layer 4.

Only two artifacts were recovered from the shovel tests. One was a small (ca. 1-cm) piece of asbestos floor tile, from Level 2 in ST 4. Asbestos was in use as an ingredient in building materials since about 1900, but was by far the most popular between 1950 and 1970 (Asbestos Resource Center 2005). The other artifact was a small tertiary chert flake from Level 1 of ST 5.

\section{Summary and Recommendations}

Following recommendations from previous archaeological survey projects in Walker Ranch Park (Tomka 1998; Weston 2003) that any sub-surface excavations in the park be preceded by archaeological testing in order to insure that important prehistoric or historic features were not destroyed, the Parks and Recreation Department of the City of San Antonio contracted with CAR to test the footprint of a proposed abutment for a footbridge over Salado Creek. Five shovel tests were excavated centered on the footprint and a backhoe trench was dug about $10 \mathrm{~m}$ west of the shovel tests.
The shovel tests varied in depth from 26 to $43 \mathrm{~cm}$ below surface (cmbs). Two artifacts were recovered from the shovel tests, a piece of asbestos tile dating to the mid-twentieth century, and a small piece of chert debitage. The tests showed two layers of silty clay over a layer of densely packed gravel. The backhoe trench, which was dug to a depth of $140 \mathrm{cmbs}$, showed that this gravel layer lies above more layers of gravel and sand, none of which show any sign of cultural deposits. Two chert flakes and one piece of bottle glass were observed in the upper $10 \mathrm{~cm}$ of the backhoe trench but were not collected.

The profile exposed in the backhoe trench and the testing of the footprint of the bridge abutment makes it clear that, with the exception of a few scattered chert flakes and recent debris, no deposits of cultural materials are present within the APE. The presence of both recent and prehistoric artifacts in the upper portion of the profiles is indicative of disturbed deposits resulting from animal burrowing and the downward movement of artifacts in cracks which form in the clay deposits. Therefore, the area is cleared for construction and it is our recommendation that no further archaeological monitoring for this project is needed.

It is important to note, however, that the potential for important intact cultural deposits in other areas of the park remains high (Greaves 2003; Tomka 1998; Weston 2003) and future construction planned within the park should be preceded by an evaluation and possibly by testing of the area by archaeologists. 


\section{References Cited}

Asbestos Resource Center

2005 What is Asbestos? Electronic database, $<$ http://www.asbestosresource.com/asbestos/products.html $>$, accessed May 5, 2006.

Black, S. L. and A. J. McGraw

1985 The Panther Springs Creek Site: Cultural Change and Continuity within the Upper Salado Creek Watershed, South-Central Texas. Archaeological Survey Report, No. 100. Center for Archaeological Research, The University of Texas at San Antonio.

Black, S. L., K. Jolly, C. D. Frederick, J. R. Lucas, J. W. Karbula, P. R. Takac, and D. R. Potter

1998 Archaeology along Wurzbach Parkway, Module 3. Investigations and Experimentation at the Higgins Site (41BX184). Vol. 1. Studies in Archeology 27. Texas Archeological Research Laboratory, The University of Texas at Austin.

Bomar, G. W.

1995 Texas Weather. University of Texas Press, Austin.

Bowden J. J.

1986 The Exodus of Federal Forces from Texas 1861. Eakin Press, Austin, Texas.

Civil War Soldiers and Sailors System

2006 Detailed Soldier Record for Charles Ganahl. National Park Service Civil War Soldiers and Sailors System. Electronic database, <http://www.itd.nps.gov/cwss/soldiers.htm>, accessed May 16, 2006.

Crimmins, M. L.

1938 An Episode in the Texas Career of General David E. Twiggs. Southwestern Historical Quarterly 41 (2):167-173.

Eckhardt, G.

2006 Introduction to the Edwards Aquifer. Electronic document, $<$ http://www.edwardsaquifer.net/intro.html $>$, accessed May 4, 2006.

Fox, A. A.

1979 Archaeological and Historical Investigations at 41BX180, Walker Ranch, San Antonio, Texas: Phase 1. Archaeological Survey Report, No. 83. Center for Archaeological Research, The University of Texas at San Antonio.

Greaves, R. D.

2003 Geoarchaeological Investigations. In Archaeological Survey and Geoarchaeological Investigations at 41BX1271, Walker Ranch Park, Bexar County, Texas, by J. D. Weston, pp.10-14. Archaeological Survey Report, No. 337. Center for Archaeological Research, The University of Texas at San Antonio.

Gregg, R. L.

2006 William Dobie. Handbook of Texas Online. Electronic database, $<$ http://www.tsha.utexas.edu/handbook/online/ articles/DD/fdo38.html>, accessed May 16, 2006. 
Gunn, J. W.

2006 The Mexican Invasions of 1842. Handbook of Texas Online. Electronic database, <http://www.tsha.utexas.edu/ handbook/online/articles/MM/qem2.html>, accessed May 16, 2006.

Habig, M. A.

1968 The Alamo Chain of Missions: A History of San Antonio's Five Old Missions. Franciscan Herald Press, Chicago.

Hudson, W. R., W. M. Lynn and D. S. Scurlock

1974 Walker Ranch: An Archaeological Reconnaissance and Excavation in North Bexar County, Texas. Office of the State Archeologist, Report 26. Texas Historical Commission, Austin.

Inglis, J. M.

1964 A History of Vegetation on the Rio Grande Plain. Bulletin No. 45. Texas Parks and Wildlife Department, Austin.

LBJ School of Public Affairs

1978 Preserving Texas'Natural Heritage. LBJ School of Public Affairs, Report 31. Austin.

Loomis, L. E., W. F. Gabriel, and B. R. Brasher

1992 Genesis of the Quihi Soil in the Uvalde Gravel of South-Central Texas. In Preliminary Draft of Late Cenozoic Alluvial Stratigraphy and Prehistory of the Inner Gulf Coastal Plain, South-Central Texas. Guidebook, 10th Annual Meeting, South-Central Friends of the Pleistocene. Lubbock Lake Landmark Quaternary Research Center Series 4:47-72.

McKinney, W. W.

1981 Early Holocene Adaptations in Central and Southwest Texas: The Problem of the Paleoindian-Early Archaic Transition. Bulletin of the Texas Archeological Society 52:91-120.

Meissner, B. A.

2000a An Archaeological Assessment of San Pedro Park (41BX19), San Antonio, Texas. Archaeological Survey Report, No. 269. Center for Archaeological Research, the University of Texas at San Antonio.

2000b Monitoring of Excavations for Construction of an Outdoor Classroom Facility at Walker Ranch Park (41BX1271), San Antonio, Texas. Letter Report, No. 127. Center for Archaeological Research, The University of Texas at San Antonio.

National Register of Historic Places

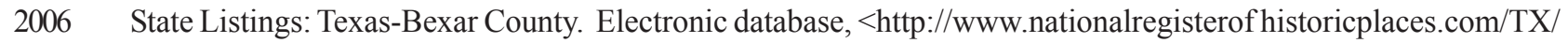
Bexar/state3.html>, accessed May 5, 2006.

Nickels, D. L., D. W. Pease, and C. B. Bousman

1997 Archaeological Survey of Lackland Air Force Base, Bexar County, Texas. Archaeological Survey Report, No. 248. Center for Archaeological Research, The University of Texas at San Antonio.

Norwine, J.

1995 The Regional Climate of South Texas: Patterns and Trends. In The Changing Climate of Texas: Predictability and Implications for the Future, edited by J. Norwine, J. R. Giardino, G. R. North and J. B. Valdez, pp. 138-154. Cartographics, Texas A\&M University, College Station, Texas. 
Official Records

2006 Official Records. The War of the Rebellion: A compilation of the Official Records of the Union and Confederate Armies. Electronic database compiled by eHistory at Ohio State University, $<$ http://ehistory.osu.edu/uscw/library/ or/index.cfm>, accessed May, 2006.

Potter, D. R.

1980 An Archaeological Assessment of 41 BX197 and Vicinity, Walker Ranch National Register Historic District, San Antonio, Texas. Archaeological Survey Report, No. 91. Center for Archaeological Research, The University of Texas at San Antonio.

Potter, D. R. and S. L. Black, and K. Jolly

1995 Archaeology along the Wurzbach Parkway, Module 1: Introduction, Conceptual Framework and Contexts of Archaeological Investigations in Bexar County, South-Central Texas. Studies in Archeology 17. Texas Archeological Research Laboratory, The University of Texas at Austin.

Riskind, D. H. and D. D. Diamond

1988 An Introduction to Environment and Vegetation. In Edwards Plateau Vegetation: Plant Ecological Studies in Central Texas, edited by B. B. Amos and F. R. Gehlbach, pp. 1-16. Baylor University Press, Waco, Texas.

Story, D. A.

1985 Adaptive Strategies of Archaic Cultures of the West Gulf Coast Plain. In Prehistoric Food Production in North America, edited by R. I. Ford, pp. 19-56. Anthropological Papers No. 75, Museum of Anthropology, University of Michigan, Ann Arbor.

Taylor, F. B., R. B. Hailey and D. L. Richard

1991 Soil Survey of Bexar County, Texas. United States Department of Agriculture, Soil Conservation Service, Washington, D.C.

Texas General Land Office [TGLO]

2006a Land Grant Surname Index. Electronic database, <http://www.glo.state.tx.us/archives/pdfs/land \%20Grant\%20D.pdf>, accessed May 16, 2006.

2006b Land Grant Search. Electronic database, <http://wwwdb.glo.state.tx.us/central/LandGrants/ landgrants.cfm?intID=148713>, accessed June, 2006.

Texas Historical Commission

2006 Texas Archeological Sites Atlas. Electronic database, <http://www.pedernales.thc.state.tx.us/>, accessed May 3, 2006.

Tomka, S. A.

1998 An Archaeological Survey of Walker Ranch Park, Bexar County, Texas. Archaeological Survey Report, No. 282. Center for Archaeological Research, The University of Texas at San Antonio.

Tomka, S. A., B. A. Meissner, and T. K. Perttula

1997 Hunter-gatherer Subsistence Practices. In Archaeology of the Rio Grande and Central Coastal Plains, Texas: A Planning Document, by S. A. Tomka, T. K. Perttula, and R. J. Hard. Archaeological Survey Report, No. 266. Center for Archaeological Research, The University of Texas at San Antonio. 
U. S. Bureau of Land Management

2006 Bottle/Glass Colors. Electronic document, <http://www.blm.gov/historic_bottles/colors.htm>, accessed June 14, 2006.

Van Auken, O. W.

1988 Woody Vegetation of the Southern Escarpment and Plateau. In Edwards Plateau Vegetation: Plant Ecological Studies in Central Texas, edited by B. B. Amos and F. R. Gehlbach, pp. 43-55. Baylor University Press, Waco, Texas.

Warner, E. J.

1959 Generals in Gray: Lives of the Confederate Commanders. Louisiana State University Press, Baton Rouge, Louisiana.

Weniger, D.

1988 Vegetation Before 1969. In Edwards Plateau Vegetation: Plant Ecological Studies in Central Texas, edited by B. B. Amos and F. R. Gehlbach, pp. 17-23. Baylor University Press, Waco, Texas.

Weston, J.D.

2003 Archaeological Survey and Geoarchaeological Investigations at 41BX1271, Walker Ranch Park, Bexar County, Texas. Archaeological Survey Report, No. 337. Center for Archaeological Research, The University of Texas at San Antonio.

Winkler, E. W. (editor)

1910 The Bexar and Dawson Prisoners. Southwestern Historical Quarterly Online 13(4). Electronic document, $<$ http://www.tsha.utexas.edu/publications/journals/shq/online/v013/n4/article_3.html >, accessed May 15, 2006. 